\title{
The combination of baicalin and baicalein enhances apoptosis via the ERK/p38 MAPK pathway in human breast cancer cells
}

\author{
Qian-mei ZHOU ${ }^{1}$, Song WANG ${ }^{1}$, Hui ZHANG ${ }^{1}$, Yi-yu $\mathrm{LU}^{1}$, Xiu-feng WANG ${ }^{1}$, Yoshiharu MOTOO ${ }^{2}$, Shi-bing SU ${ }^{1, *}$ \\ ${ }^{1}$ Research Center for Traditional Chinese Medicine Complexity System, Shanghai University of Traditional Chinese Medicine, Shanghai \\ 201203, China; ${ }^{2}$ Department of Medical Oncology, Kanazawa Medical University, Uchinada, Ishikawa 920-0293 Japan
}

\begin{abstract}
Aim: To examine whether the cell growth inhibitory effect of the combination of baicalin and baicalein is related to apoptosis. Moreover, to determine whether the expression of some apoptosis-related proteins is regulated by the ERK/p38 MAPK pathway. Methods: Cell viability was measured using a 3-(4,5-dimethylthiazol-2-yl)-2, 5-diphenyltetrazolium bromide (MTT) assay. Apoptosis was detected by acridine orange (AO) staining, DNA ladder assay and flow cytometric analysis. Apoptosis-related proteins were observed using Western blot analysis.

Results: Compared with baicalin or baicalein alone, the combination treatment of baicalin ( $50 \mu \mathrm{mol} / \mathrm{L})$ and baicalein $(25 \mu \mathrm{mol} / \mathrm{L}) \mathrm{had}$ an anti-proliferative effect in a time-dependent manner. Isobologram analysis demonstrated that the combination treatment had a synergistic effect. Moreover, apoptosis in MCF-7 cells was increased by $12 \%$ and $20 \%$ with the combination treatment at $24 \mathrm{~h}$ and $48 \mathrm{~h}$, respectively. With the combination treatment in MCF-7 cells, cleaved caspase- 3 and caspase- 9 were observed, and the level of bcl-2 expression was decreased approximately $20 \%$ and $40 \%$ at $24 \mathrm{~h}$ and $48 \mathrm{~h}$, respectively. The expression of bax and p53 were increased about $25 \%$ and $15 \%$ at $48 \mathrm{~h}$, respectively. Moreover, the activation of caspase-3, -9 and the regulation of bcl-2, bax and p53 were related to ERK /p38 MAPK activation.

Conclusion: In this study, apoptosis was enhanced by the combination treatment of baicalin and baicalein, which activated caspases-3 and caspase-9, downregulated the level of bcl-2 and upregulated the level of bax or p53 via the ERK/p38 MAPK pathway.
\end{abstract}

Keywords: baicalin; baicalein; combination therapy; apoptosis; breast cancer cells

Acta Pharmacologica Sinica (2009) 30: 1648-1658; doi: 10.1038/aps.2009.166

\section{Introduction}

Cancer is the second leading cause of death worldwide ${ }^{[1]}$. Breast cancer is the most common cancer among women, comprising $23 \%$ of all female cancers around the globe ${ }^{[2]}$. There is a lifetime risk of up to $12 \%$ and a risk of death of up to $5 \%{ }^{[3]}$ in breast cancer. Although the incidence rates of breast cancer in the world have increased by about $0.5 \%$ annually since 1990, cancer registries in China recorded annual increases in incidence of $3 \%-4 \%{ }^{[4]}$. There have been great advancements in the treatment and control of breast cancer, but significant deficiencies still remain.

It is well known that cell homeostasis requires a balance between cell proliferation and cell death, including apoptosis $^{[5]}$. Moreover, there is strong evidence that tumor growth is a result not only of uncontrolled proliferation but

* To whom correspondence should be addressed.

E-mail shibingsu@shutcm.edu.cn

Received 2009-06-15 Accepted 2009-10-14 also of reduced apoptosis ${ }^{[6]}$. Therefore, induction of apoptosis has become an effective means of cancer therapy.

Apoptosis has been defined as a discrete sequence of morphological changes resulting in cell death with extensive dsDNA cleavage accompanied by chromatin compaction and segregation along the nuclear membrane ${ }^{[7]}$. Many death and survival genes, such as bcl- $2^{[8]}$ or bax ${ }^{[9]}$, which are regulated by extracellular factors, are involved in apoptosis. Additionally, recent reports indicate that one of the molecular events of apoptosis is activation of the caspases by a signal transduction cascade $^{[10]}$.

Currently, chemotherapy using plant-derived, anti-cancer drugs such as paclitaxe ${ }^{[11]}$, vinorelbine ${ }^{[12]}$, or vincristine ${ }^{[13]}$ has been proven to be effective in clinical settings. It was shown that these products enhance cell growth inhibition in different cancer cell lines and are highly effective and safe in clinical trials.

Baicalin and baicalein are components of Baikal Skullcap Root. It has been reported that either baicalin or baicalein has 
potential anti-tumor effects on liver ${ }^{[14]}$, prostate ${ }^{[15]}$, bladder ${ }^{[16]}$, and breast cancer cells ${ }^{[17,18]}$. However, the anti-tumor effect of combination treatment with baicalin and baicalein on breast cancer cells is not clear.

Mitogen-activated protein kinase (MAPK) pathways have been implicated in the response to chemotherapeutic drugs ${ }^{[19]}$. The proteins involved in MAPK cascades are expressed and respond to a wide variety of external cues and drugs. P38 MAPK has been implicated in the regulation of various cellular processes ${ }^{[20]}$. Previous reports have shown that MEK, which is activated by mitogenic stimuli, contributes to cell differentiation, proliferation, and survival ${ }^{[21]}$. Some responsiveness was regulated by ERK and MAPK in breast cancer cells ${ }^{[22]}$. It is of interest, therefore, to determine whether apoptosis is induced by the combination of baicalin and baicalein via the ERK/p38 MAPK signaling pathway.

In this study, we demonstrate that the combination treatment of baicalin and baicalein enhances the growth-inhibitory effect in human breast cancer cells. Furthermore, we report that the growth-inhibitory effect derives from the induction of apoptosis, which involves activation of caspase- 3 and caspase-9, downregulation of bcl-2 expression and upregulation of bax or p53 expression via ERK/p38 MAPK pathway.

\section{Materials and methods Materials}

Baicalin and baicalein were obtained from National Institute for the Control of Pharmaceutical and Biological Products, China and dissolved in dimethyl sulfoxide (DMSO). Acridine orange (AO), Annexin $\mathrm{V}$ and propidium iodide (PI) were from Sigma (St Louis, MO, USA). The antibodies against caspase-9, caspase-3, bcl-2, bax, p-ERK, and p-p38 were obtained from Cell Signaling Technology (Boston, MA, USA). The anti-p53 antibody was from Santa Cruz Biotechnology (Santa Cruz, CA, USA). PD98059 and SB203580 were from Biomol (Philadelphia, PA, USA).

\section{Cell culture}

Human breast cancer MCF-7 and MDA-MB-231 cells were obtained from American Type Culture Collection (Manassas, VA, USA) and were cultured in RPMI-1640 medium (Gibco, San Francisco, CA, USA) supplemented with 10\% heat-inactivated $\left(56^{\circ} \mathrm{C}, 30 \mathrm{~min}\right.$ ) fetal calf serum (PAA, A-4061, Pasching, Austria ), $0.01 \mathrm{mg} / \mathrm{mL}$ insulin (Sigma, St Louis, MO, USA), $2 \mathrm{mmol} / \mathrm{L}$ glutamine (Gibco, San Francisco, CA, USA), penicillin $(100 \mathrm{U} / \mathrm{mL})$ and streptomycin $(100 \mu \mathrm{g} / \mathrm{mL})$. The cell culture was maintained at $37^{\circ} \mathrm{C}$ with $5 \% \mathrm{CO}_{2}$ in a humidified atmosphere.

\section{Cell growth assay}

The inhibition of cell growth was determined by MTT assay. MCF-7 and MDA-MB-231 cells $\left(5 \times 10^{4}\right.$ cells $\left./ \mathrm{mL}\right)$ were seeded in 96-well culture plates. After overnight incubation, MCF-7 cells were treated with various concentrations of baicalin, baicalein, or baicalin plus baicalein (The ratio of two compounds was 1:1 and the concentration of each compound was condensed one fold) with or without PD98059 or SB203580. MDA-MB-231 cells were treated with various concentrations of baicalin, baicalein, or baicalin plus baicalein. Following incubation, cell growth was measured at different time points after the addition of $20 \mu \mathrm{L}$ MTT at $37^{\circ} \mathrm{C}$ for $4 \mathrm{~h}$. Then DMSO $(150 \mu \mathrm{L})$ was added to dissolve the formazan crystals. Optical density (OD) was measured at $490 \mathrm{~nm}$ with an ELISA plate reader (BioTek, Winooski, Vermont, USA). The percentage of inhibition was calculated as follows:

$$
\text { Inhibition rate }(\mathrm{IR})(\%)=\left(1-\frac{O D_{\text {Sample }}}{O D_{\text {Control }}}\right) \times 100 \%
$$

\section{Analysis of the effects of combinations of drugs}

Isobologram analysis was used to determine the effects of drug combinations on MCF-7 and MDA-MB-231 cells. The interaction of two compounds was quantified by determining the combination index (CI), in accordance with the following classic isobologram ${ }^{[23]}$ :

$$
\mathrm{CI}=(\mathrm{D})_{1} /(\mathrm{Dx})_{1}+(\mathrm{D})_{2} /(\mathrm{Dx})_{2}
$$

Where $\mathrm{Dx}$ is the dose of one drug alone required to produce an effect, and $(D)_{1}$ and $(D)_{2}$ are the doses of compounds 1 and 2 , respectively, necessary to produce the same effect in combination. From this analysis, the combined effects of the two drugs can be summarized as follows: The CI of less than, equal to, or more than 1 indicate synergistic, additive, or antagonistic effects, respectively.

\section{Cellular morphological observation}

The cellular morphology was investigated as previously reported $^{[24]}$. MCF-7 and MDA-MB-231 cells $\left(2 \times 10^{5} / \mathrm{mL}\right)$ were seeded in 6-well plates and cultured overnight. Once the cells had anchored to the plates, MCF-7 cells were treated with $50 \mu \mathrm{mol} / \mathrm{L}$ baicalin, $25 \mu \mathrm{mol} / \mathrm{L}$ baicalein or $50 \mu \mathrm{mol} / \mathrm{L}$ baicalin plus $25 \mu \mathrm{mol} / \mathrm{L}$ baicalein with or without PD98059 or SB203580. MDA-MB-231 cells were treated with $50 \mu \mathrm{mol} / \mathrm{L}$ baicalin, $25 \mu \mathrm{mol} / \mathrm{L}$ baicalein or $50 \mu \mathrm{mol} / \mathrm{L}$ baicalin plus 25 $\mu \mathrm{mol} / \mathrm{L}$ baicalein. After treatment for $24 \mathrm{~h}$ and $48 \mathrm{~h}$ in MCF-7 cells or $48 \mathrm{~h}$ in MDA-MB-231 cells, cells were harvested and washed twice with phosphate-buffered saline (PBS) then stained with $\mathrm{AO}(10 \mathrm{mg} / \mathrm{L})$ at $37^{\circ} \mathrm{C}$ for $10 \mathrm{~min}$. Slides were sealed with coverslips and fluorescence was observed under a microscope $(400 \times)$ (Olympus, Tokyo, JAPAN) with a green filter.

\section{DNA gel electrophoresis assay}

MCF-7 or MDA-MB-231 cells were incubated with both baicalin and baicalein alone or together for different time points. DNA extraction was performed according to the manufacturer's instructions (TIANGEN BIOTECH, Beijing, China). Electrophoresis was performed in $1.5 \%$ agarose gel (containing 0.5 $\mu \mathrm{g} / \mathrm{mL}$ ethidium bromide) for $1 \mathrm{~h}$, and the bands were visualized and photographed under transmitted ultraviolet light.

\section{Flow cytometric analysis}

The MCF-7 cells $\left(10^{6} / \mathrm{mL}\right)$ were cultured in 6-well plates until $70 \%-80 \%$ confluent. Cells were then treated with $50 \mu \mathrm{mol} / \mathrm{L}$ 
baicalin, $25 \mu \mathrm{mol} / \mathrm{L}$ baicalein or $50 \mu \mathrm{mol} / \mathrm{L}$ baicalin plus 25 $\mu \mathrm{mol} / \mathrm{L}$ baicalein for 12, 24, or $48 \mathrm{~h}$. Cells were collected and the annexin V-PI dual-staining assay or PI staining was performed according to the manufacturer's instructions. The cells were analyzed using a FACS Aria cytometer (BD FACSAria, San Jose, CA, USA). The percentage of apoptotic cell population and cell cycle were determined using ModFit LT 3.0 software.

\section{Western blot analysis}

Whole cell lysate was loaded in each lane and separated by $12 \%$ SDS-PAGE. Protein expression was detected using primary antibody (1:1000, except p53 1:200) and secondary antibody (1:800) conjugated with horseradish peroxidase. Levels of p53, caspase-3, -9, bcl-2, bax, p-ERK, p-p38, and GAPDH were analyzed in this manner. Chemiluminescence was observed by ECL (Pharmacia, Buckinghamshire, UK). Quantitative analysis of Western blotting was done using Alpha Ease FC (FluorChem FC2) software. Using the analysis tools, we calculated the density ratio of protein to GAPDH, the loading control.

\section{Statistical analysis}

All data are expressed as means \pm SD. Comparisons between groups were performed by Student's $t$-test and one-way analysis of variance (ANOVA). The level of significance was set at $P<0.05$.

\section{Results}

Combination treatment with baicalin and baicalein enhances the effect of each drug on human breast cancer cell growth

Cells were incubated with a range of concentrations of baicalin and baicalein for $72 \mathrm{~h}$. Cell viability was determined by MTT assay. Upon treatment with baicalin or baicalein, cell viability decreased in a concentration-dependent manner. For combination treatment, the lowest effective dosage of each compound was combined with a range of doses of the other compound. Consequently, we tested both the combination of baicalein $(25 \mu \mathrm{mol} / \mathrm{L})$ plus a range of concentrations of baicalin and the combination of baicalin $(50 \mu \mathrm{mol} / \mathrm{L})$ plus a range of concentrations of baicalein on MCF-7 cells (Figure 1A, 1B).

After treatment with the combination of baicalein at 25 $\mu \mathrm{mol} / \mathrm{L}$ plus baicalin at $50 \mu \mathrm{mol} / \mathrm{L}$, cell growth inhibition was increased about $26 \%$ as compared to baicalin at $50 \mu \mathrm{mol} / \mathrm{L}$ alone $(P<0.05)$. Similarly, after treatment with the combination of baicalein at $25 \mu \mathrm{mol} / \mathrm{L}$ plus baicalin at $75 \mu \mathrm{mol} / \mathrm{L}$, cell growth inhibition was increased about $15 \%$ as compared to baicalin at $75 \mu \mathrm{mol} / \mathrm{L}$ alone $(P<0.05)$. Cell growth inhibition was not significantly changed when we combined baicalein at $25 \mu \mathrm{mol} / \mathrm{L}$ with baicalin at 100, 150, or $200 \mu \mathrm{mol} / \mathrm{L}(P>0.05)$, as compared to baicalin at 100, 150, or $200 \mu \mathrm{mol} / \mathrm{L}$ alone (Figure 1A). Moreover, there were no significant differences between baicalein at $25 \mu \mathrm{mol} / \mathrm{L}$ plus baicalin at $50 \mu \mathrm{mol} / \mathrm{L}$, baicalein at $25 \mu \mathrm{mol} / \mathrm{L}$ plus baicalin at $75 \mu \mathrm{mol} / \mathrm{L}$ and baicalein at 25 $\mu \mathrm{mol} / \mathrm{L}$ plus baicalin at $100 \mu \mathrm{mol} / \mathrm{L}(P>0.05)$.

After combination treatment of baicalin at $50 \mu \mathrm{mol} / \mathrm{L}$ plus baicalein at $25 \mu \mathrm{mol} / \mathrm{L}$ or combination treatment of baicalin at $50 \mu \mathrm{mol} / \mathrm{L}$ plus baicalein at $50 \mu \mathrm{mol} / \mathrm{L}$, cell growth inhibition was increased about $30 \%$ and $19 \%$, as compared to baicalein at $25 \mu \mathrm{mol} / \mathrm{L}$ or $50 \mu \mathrm{mol} / \mathrm{L}$ alone, respectively. These changes were significant $(P<0.05)$. However, baicalin at $50 \mu \mathrm{mol} / \mathrm{L}$ plus baicalein at $100 \mu \mathrm{mol} / \mathrm{L}, 200 \mu \mathrm{mol} / \mathrm{L}$, or $400 \mu \mathrm{mol} / \mathrm{L}$ did not change the effect on cell survival $(P>0.05)$, as compared to baicalein at $100 \mu \mathrm{mol} / \mathrm{L}, 200 \mu \mathrm{mol} / \mathrm{L}$ or $400 \mu \mathrm{mol} / \mathrm{L}$ alone (Figure 1B). There were no significant differences between baicalin at $50 \mu \mathrm{mol} / \mathrm{L}$ plus baicalein at $25 \mu \mathrm{mol} / \mathrm{L}$, baicalin at $50 \mu \mathrm{mol} / \mathrm{L}$ plus baicalein at $50 \mu \mathrm{mol} / \mathrm{L}$ and baicalin at 50 $\mu \mathrm{mol} / \mathrm{L}$ plus baicalein at $100 \mu \mathrm{mol} / \mathrm{L}(P>0.05)$.

Cell growth was maximally inhibited by combination treatment with baicalin $50 \mu \mathrm{mol} / \mathrm{L}$ and baicalein $25 \mu \mathrm{mol} / \mathrm{L}$, as compared to all other combinations of concentrations, even combinations in which both drugs were used at higher concentrations. It was also found, by isobologram analysis, that the combination of $50 \mu \mathrm{mol} / \mathrm{L}$ baicalin and $25 \mu \mathrm{mol} / \mathrm{L}$ baicalein created a synergistic effect $(\mathrm{CI}=0.75)$. For this reason, the combination of $50 \mu \mathrm{mol} / \mathrm{L}$ baicalin and $25 \mu \mathrm{mol} / \mathrm{L}$ baicalein was used in the following experiments. We next examined cell growth inhibition in a time course study. MCF-7 cells were treated with $50 \mu \mathrm{mol} / \mathrm{L}$ baicalin, $25 \mu \mathrm{mol} / \mathrm{L}$ baicalein or their combination for 24,48 , and $72 \mathrm{~h}$ and assayed for cell viability. Figure $1 \mathrm{C}$ demonstrates that there was a time-dependent inhibition in cell growth following the combination treatment, which was significantly faster than the cell growth inhibition caused by baicalin or baicalein alone $(P<0.05)$.

To observe cell growth inhibition in another human breast cancer cell line, MDA-MB-231 cells were treated with the same drugs at the same concentrations, producing similar results, as shown in Figure 1. These data suggest that baicalin in combination with baicalein significantly inhibits human breast cancer cell growth.

\section{Baicalin combined with baicalein enhances apoptosis and} induces cell cycle arrest in MCF-7 cells

As determined by AO staining, programmed cell death was not affected by baicalin or baicalein exposure for $48 \mathrm{~h}$, but the combination of baicalin and baicalein resulted in cell shrinkage and half-moon green or saffron yellow fluorescence, which are the typical patterns of apoptosis at the indicated time points (Figure 2A). To examine the effects of the apoptotic program, we analyzed DNA fragmentation. We saw a typical DNA ladder when cells were treated with $50 \mu \mathrm{mol} / \mathrm{L}$ baicalin or 25 $\mu \mathrm{mol} / \mathrm{L}$ baicalein for $48 \mathrm{~h}$. However, the DNA ladder was significantly increased when MCF-7 or MDA-MB-231 cells were treated with the combination of baicalin and baicalein for $48 \mathrm{~h}$ (Figure 2B).

To determine the apoptosis ratio caused by the drug combination, apoptosis was analyzed by flow cytometry after $10^{6} / \mathrm{mL}$ MCF-7 cells were exposed to $50 \mu \mathrm{mol} / \mathrm{L}$ baicalin, $25 \mu \mathrm{mol} / \mathrm{L}$ baicalein or $50 \mu \mathrm{mol} / \mathrm{L}$ baicalin plus $25 \mu \mathrm{mol} / \mathrm{L}$ baicalein for 12,24 , and $48 \mathrm{~h}$. The combination significantly increased apoptosis at 24 and $48 \mathrm{~h}(P<0.01)(12 \%$ and $20 \%$, respectively), as compared to either drug alone; when baicalin 


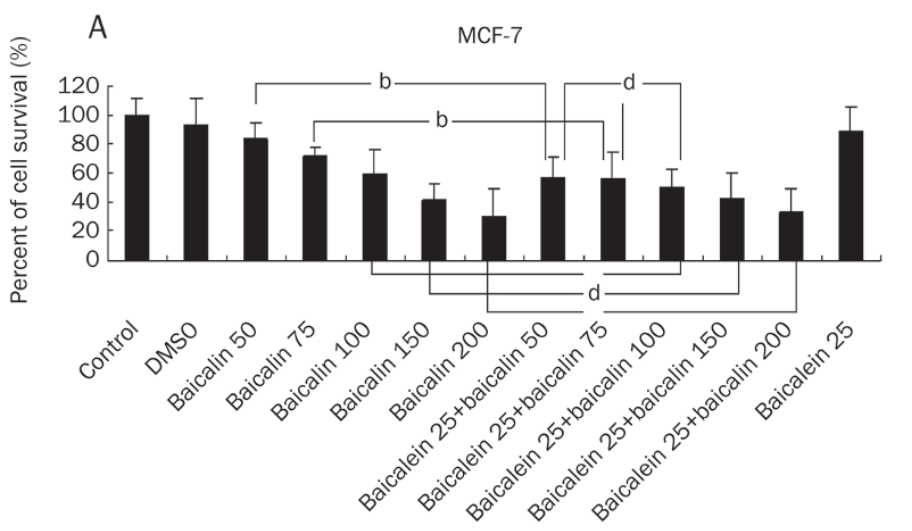

B
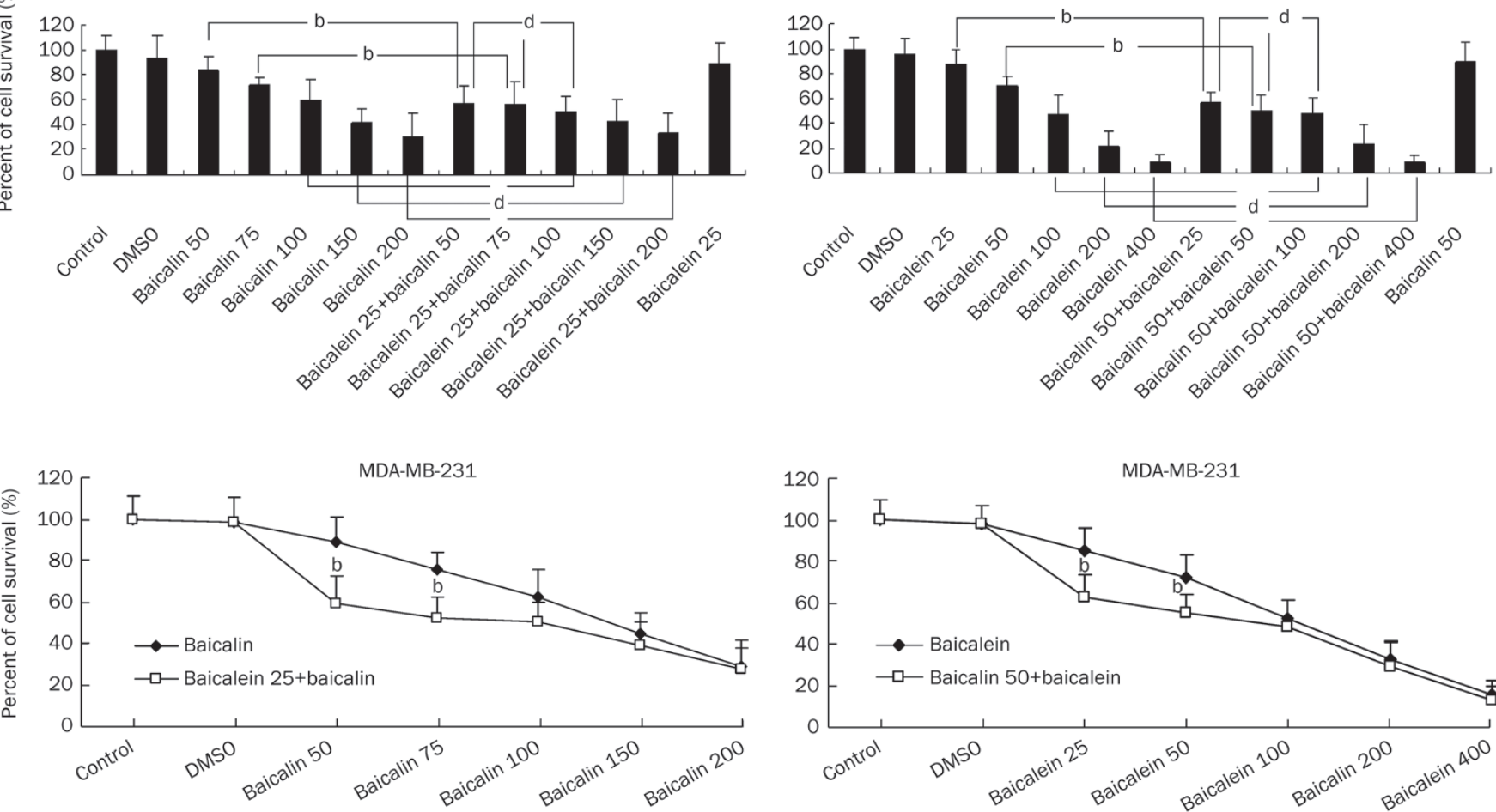

C
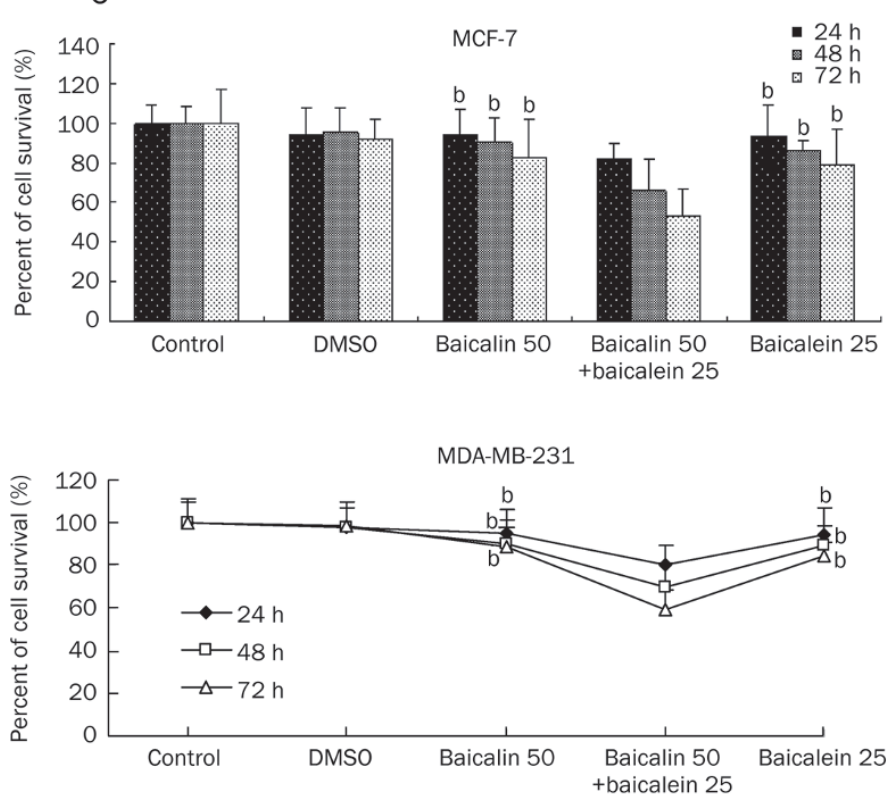

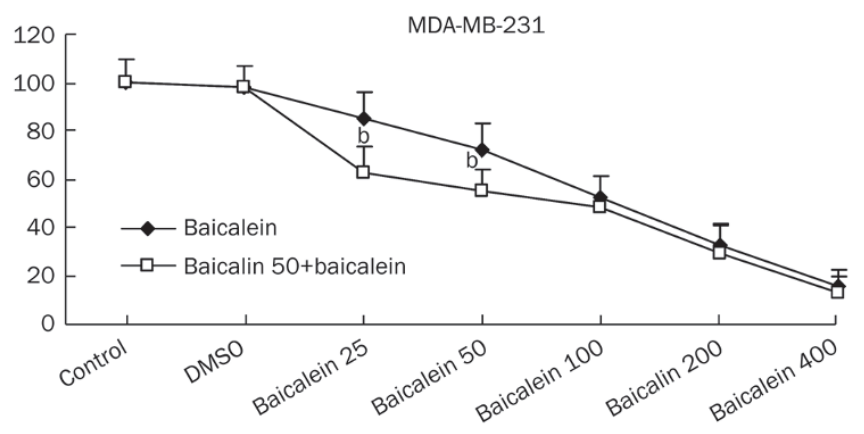

Figure 1. Effect of baicalin, baicalein, and their combination on cell viability of MCF-7 and MDA-MB-231 cells. (A) MCF-7 and MDA-MB-231 cells $\left(5 \times 10^{4}\right.$ cells $\left./ \mathrm{mL}\right)$ were treated with baicalin $50,75,100,150$, and $200 \mu \mathrm{mol} / \mathrm{L}$ with or without baicalein 25 $\mu \mathrm{mol} / \mathrm{L}$ for $72 \mathrm{~h} .{ }^{\mathrm{b}} \mathrm{P}<0.05$ (Student's $t$-test). ${ }^{\mathrm{d}} \mathrm{P}>0.05$ (One Way ANOVA). (B) MCF-7 and MDA-MB-231 cells $\left(5 \times 10^{4}\right.$ cells $\left./ \mathrm{mL}\right)$ were treated with baicalein $25,50,100,200$, and $400 \mu \mathrm{mol} / \mathrm{L}$ with or without baicalin $50 \mu \mathrm{mol} / \mathrm{L}$ for $72 \mathrm{~h} .{ }^{\mathrm{b}} \mathrm{P}<0.05$ (Student's t-test analysis). ${ }^{d} P>0.05$ (One Way ANOVA analysis). (C) MCF-7 and MDA-MB-231 cells $\left(5 \times 10^{4}\right.$ cells $\left./ \mathrm{mL}\right)$ were treated with baicalin $50 \mu \mathrm{mol} / \mathrm{L}$, baicalein $25 \mu \mathrm{mol} / \mathrm{L}$ and the combination for 24,48 , and 72 h. ${ }^{b} P<0.05$ vs the combination treatment. Values are means $\pm S D$ from 3 independent experiments. or baicalein was used alone, only $2.7 \%$ and $5.3 \%$ of cells were apoptotic at $48 \mathrm{~h}$, respectively. Moreover, there was little apoptosis at other time points (Table 1). The combination of baicalin and baicalein not only enhanced apoptosis, but also induced cell cycle arrest. As shown in Figure 3, the fraction of cells in the $G_{0} / G_{1}$ phase was increased by $17.25 \%$ or $14.62 \%$ with the combination treatment, as compared to baicalin or baicalein at $48 \mathrm{~h}$, respectively. These data show that the combination of baicalin and baicalein causes cells to arrest in $\mathrm{G}_{0} / \mathrm{G}_{1}$.

The combination of baicalin and baicalein activates caspase- 9 and caspase-3, decreases the level of bcl-2 and increases the expression of bax, p53, p-ERK, and p-p38

To determine which proteins are regulated by the drug combination treatment, we analyzed the protein levels of caspase-9, 
Table 1. Apoptosis ratio of combination treatment with baicalin and baicalein.

\begin{tabular}{cccrr}
\hline & Baicalin & Baicalein & Combination & $P$ value \\
\hline $12 \mathrm{~h}$ & $0.02 \% \pm 0.02 \%$ & $0.07 \% \pm 0.02 \%$ & $0.13 \% \pm 0.06 \%$ & $0.055,0.17$ \\
$24 \mathrm{~h}$ & $0.05 \% \pm 0.05 \%$ & $0.20 \% \pm 0.05 \%$ & $12.27 \% \pm 1.68 \%$ & $0.00023,0.00024$ \\
$48 \mathrm{~h}$ & $2.75 \% \pm 0.92 \%$ & $5.25 \% \pm 1.35 \%$ & $20.14 \% \pm 1.89 \%$ & $0.00014,0.00038$ \\
\hline
\end{tabular}

$P$ value shows that the combination was compared with baicalin and baicalein, respectively.

A $\quad$ MCF-7
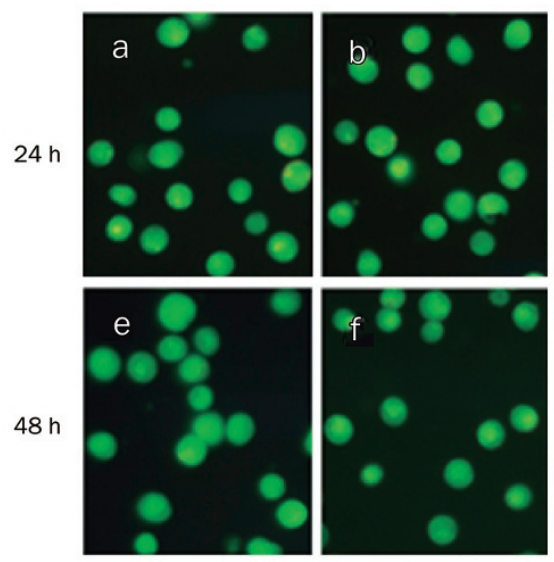

MDA-MB-231
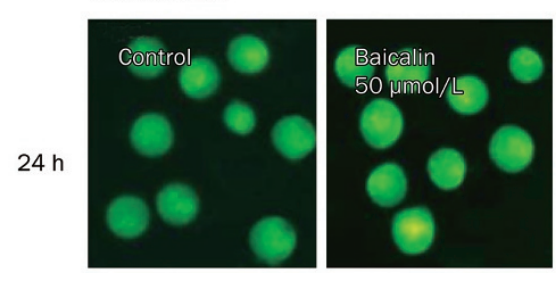
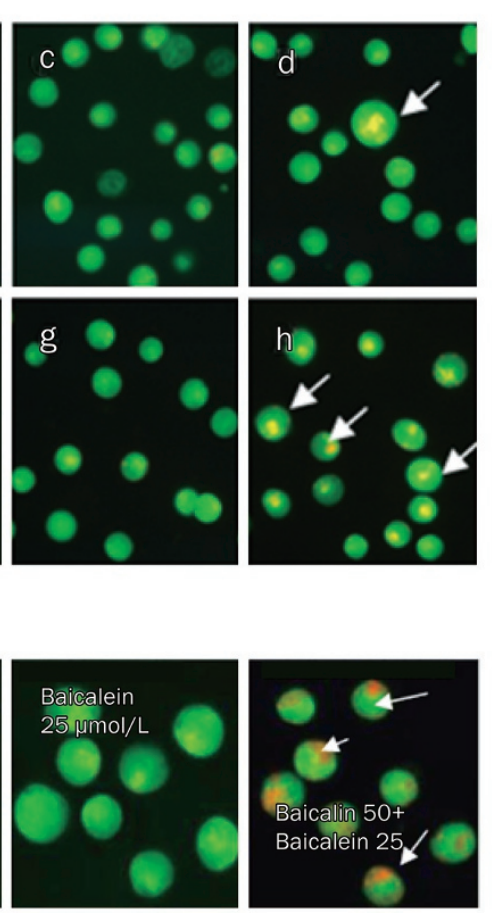

B
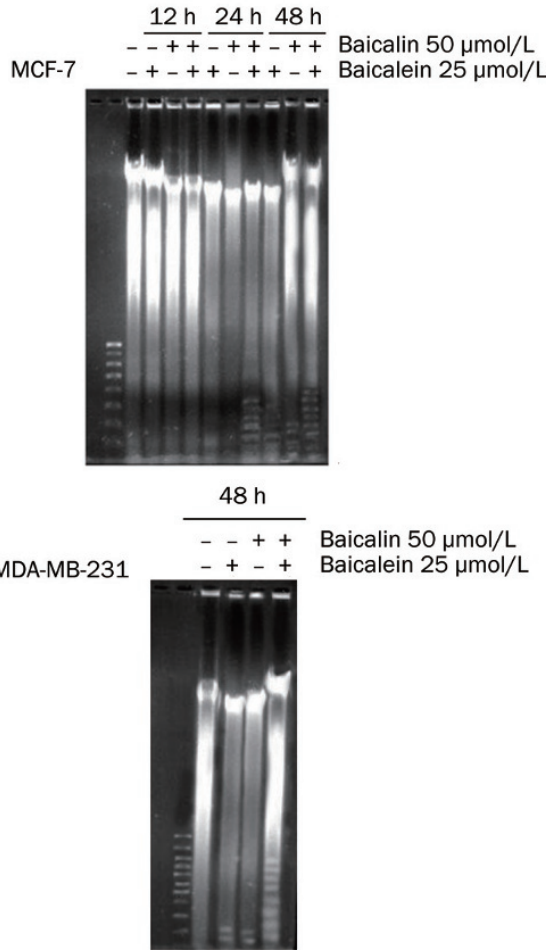

Figure 2. Effect of baicalin, baicalein and their combination on apoptosis. (A) MCF-7 cells $\left(1 \times 10^{6} / \mathrm{mL}\right)$ were exposed to baicalin $50 \mu \mathrm{mol} / \mathrm{L}$, baicalein $25 \mu \mathrm{mol} / \mathrm{L}$ or their combination for 24 and $48 \mathrm{~h}$. MDA-MB-231 cells were treated with baicalin $50 \mu \mathrm{mol} / \mathrm{L}$, baicalein $25 \mu \mathrm{mol} / \mathrm{L}$ and baicalin $50 \mu \mathrm{mol} / \mathrm{L}$ plus baicalein $25 \mu \mathrm{mol} / \mathrm{L}$ for $48 \mathrm{~h}$. Cells were stained with AO, and then observed under fluorescence microscope $(\times 400)$. (A/E), control; (B/F), 50 $\mu \mathrm{mol} / \mathrm{L}$ baicalin; $(\mathrm{C} / \mathrm{G}), 25 \mu \mathrm{mol} / \mathrm{L}$ baicalein; $(\mathrm{D} / \mathrm{H})$, combination for 24 or $48 \mathrm{~h}$, respectively in MCF-7 cells. (B) Agarose gel electrophoresis assay for DNA fragmentation. MCF-7 cells were treated with baicalin $50 \mu \mathrm{mol} / \mathrm{L}$, baicalein $25 \mu \mathrm{mol} / \mathrm{L}$ and their combination for 12,24 , and $48 \mathrm{~h}$. MDA-MB-231 cells were treated with baicalin $50 \mu \mathrm{mol} / \mathrm{L}$, baicalein $25 \mu \mathrm{mol} / \mathrm{L}$ and their combination for $48 \mathrm{~h} . n=3$.
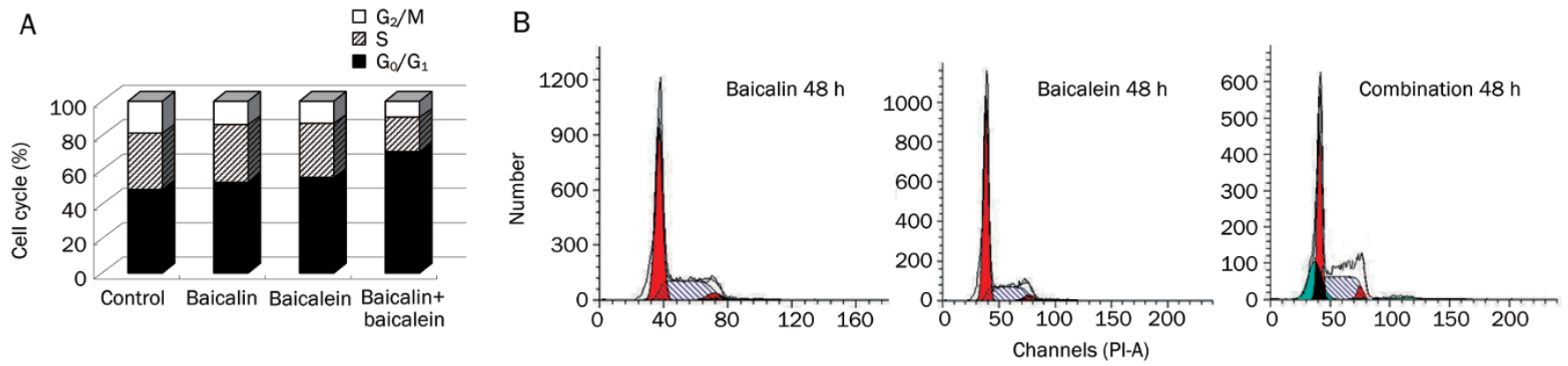

Figure 3. Effects of baicalin, baicalein, and their combination on cell cycle. MCF-7 cells $\left(1 \times 10^{6} / \mathrm{mL}\right)$ were exposed to baicalin $50 \mu \mathrm{mol} / \mathrm{L}$, baicalein 25 $\mu \mathrm{mol} / \mathrm{L}$ and their combination for $48 \mathrm{~h}$. MCF-7 cells were stained with PI, and then observed by flow cytometry. (A) Quantity of cells in different phase. (B) Representative flow cytometric profiles. $n=3$. 

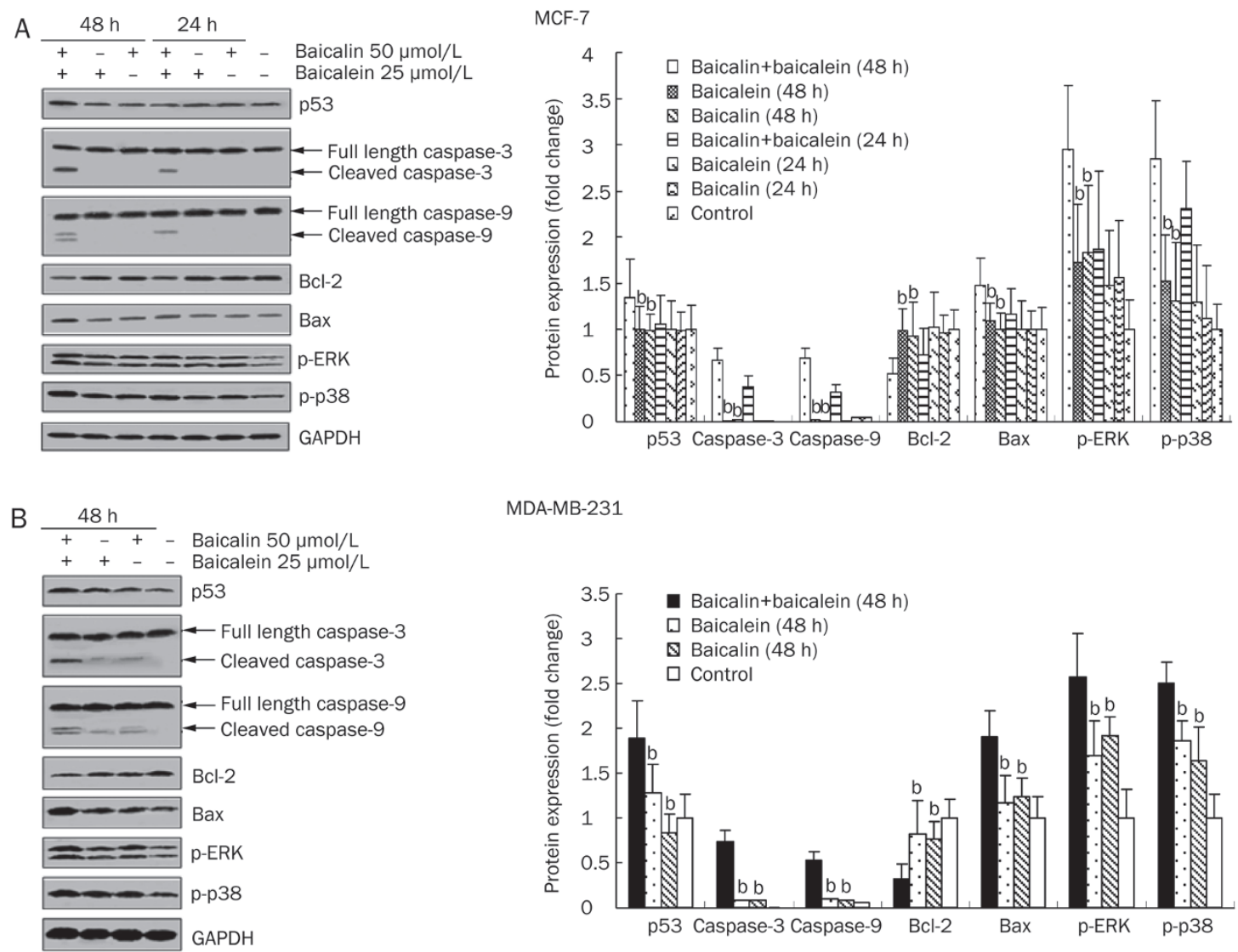

MDA-MB-231

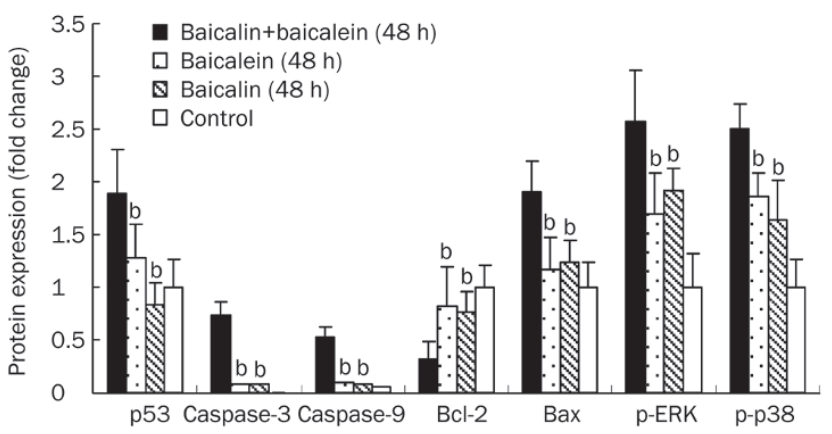

Figure 4. The expressions of p53, caspase-3, caspase-9, bcl-2, bax, p-ERK, and p-p38 by baicalin $50 \mu \mathrm{mol} / \mathrm{L}$, bacalein $25 \mu \mathrm{mol} / \mathrm{L}$ and their combination. (A) MCF-7 cells were treated with baicalin, baicalein, and baicalin plus baicalein for 24 and $48 \mathrm{~h}$. (B) MDA-MB-231 cells were treated with baicalin, baicalein, and baicalin plus baicalein for $48 \mathrm{~h}$. Then Western blot analysis was performed for p53, cleaved caspase-3, -9 , bcl-2, bax, p-ERK, and $\mathrm{p}$-p38. ${ }^{\mathrm{b}} \mathrm{P}<0.05$ compared with the combined treatment for $48 \mathrm{~h}$. The density ratio of proteins to GAPDH was shown as relative expression. Values are expressed mean \pm SD. $n=3$. Experiments were repeated with similar results.

caspase-3, the bcl-2 family including bax and p53. As shown in Figure 4 (A and B), caspase- 9 and caspase- 3 cleavage products were observed upon treatment with the drug combination at $48 \mathrm{~h}$ in both MCF-7 and MDA-MB-231 cells. However, the activation of caspase- 9 or caspase- 3 was not affected by baicalin or baicalein alone.

The level of bcl-2 was decreased by the combined drug treatment at $48 \mathrm{~h}$ (Figure 4). In contrast, the levels of bax and p53 in MCF-7 cells were increased about 25\% and 15\% after the combined drug treatment at $48 \mathrm{~h}$, as compared to the untreated control. However, the levels of these proteins remained unchanged by treatment with baicalin or baicalein alone.

To determine whether the effects of the combined drug treatment include activation of ERK or p38 MAPK, we analyzed the phosphorylation of ERK and p38 MAPK. As shown in Figure 4, the expressions of p-ERK and p-p38 were increased about 2.96- and 2.85-fold by the combined drug treatment at $48 \mathrm{~h}$ respectively, as compared to the untreated control. These data show that the combined drug treatment also affects p-ERK and p-p38.
The combination of baicalin and baicalein inhibits cell growth and enhances apoptosis via the ERK/p38 MAPK pathway

To assess the role of ERK and p38 MAPK in the combined drug treatment, cells were treated with the ERK-specific inhibitor, PD98059, and the p38 MAPK-specific inhibitor, SB203580, alone and with different drugs. As shown in Figure 5A, cell viability was analyzed by MTT assay. MCF-7 cells were treated with baicalin or baicalein alone or in combination with PD98059 or SB203580 for 24, 48, and $72 \mathrm{~h}$. The combination of baicalin and baicalein resulted in a 15\%, 24\%, and 37\% decrease in cell growth inhibition in the presence of PD98059 or SB203580 for 24, 48, and $72 \mathrm{~h}$, respectively. These data suggest that the cell growth inhibition caused by the combined drug treatment is dependent on the ERK/p38 MAPK pathway.

To explore whether the cell growth inhibition caused by the combined drug treatment is related to apoptosis, cellular morphology was observed by AO staining. MCF-7 cells were incubated with baicalin or baicalein with or without PD98059 or SB203580 for $48 \mathrm{~h}$. Figure 5B showed that the typical pattern of apoptosis was observed by the combination treat- 


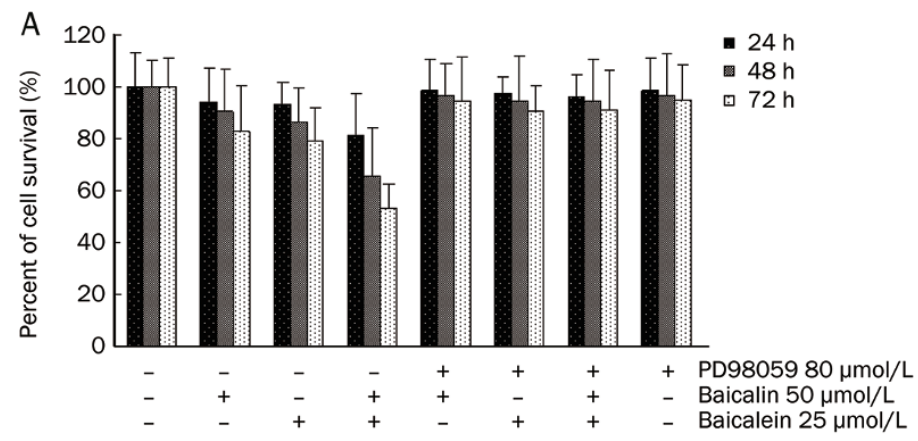

C
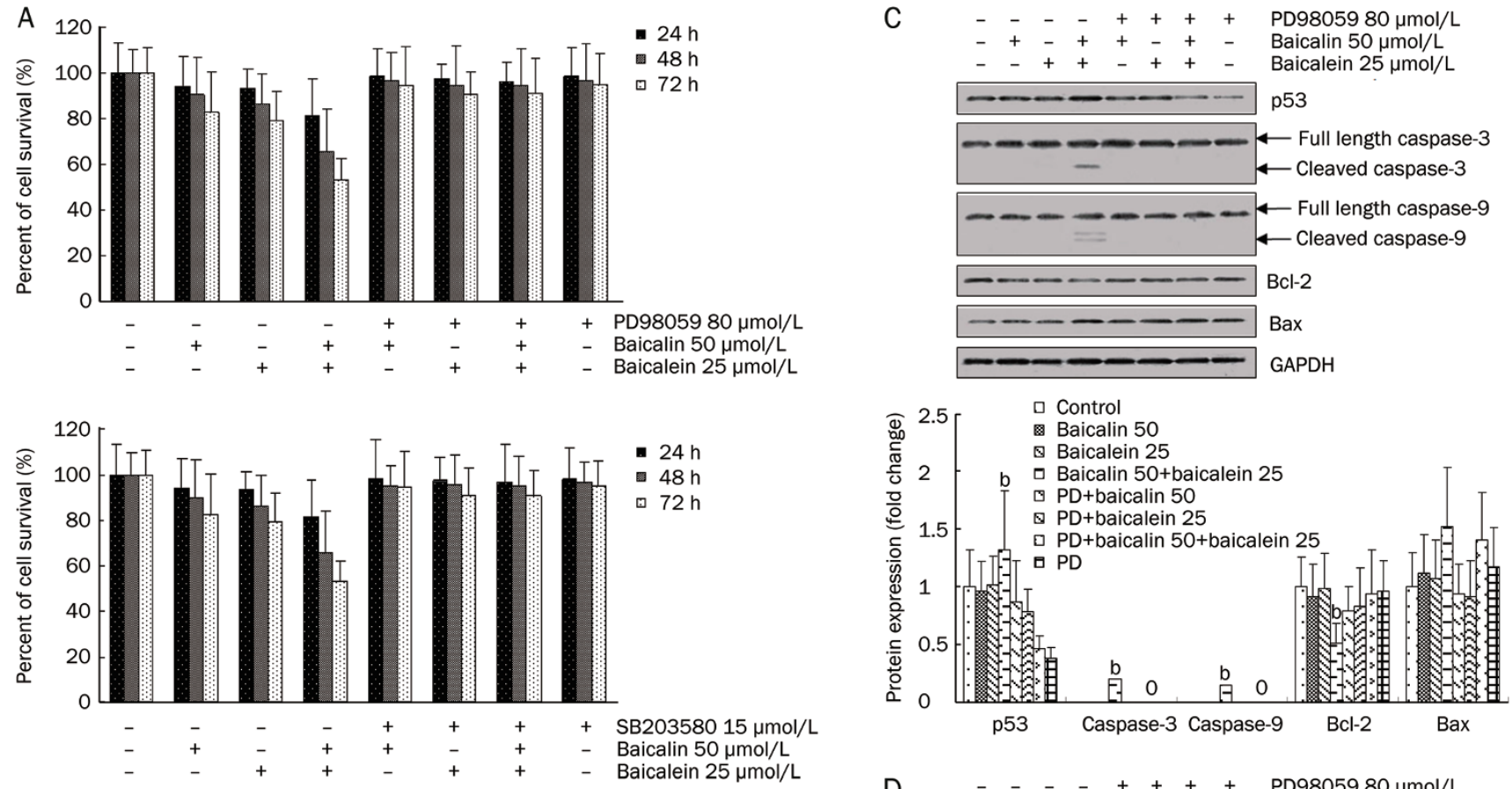

B
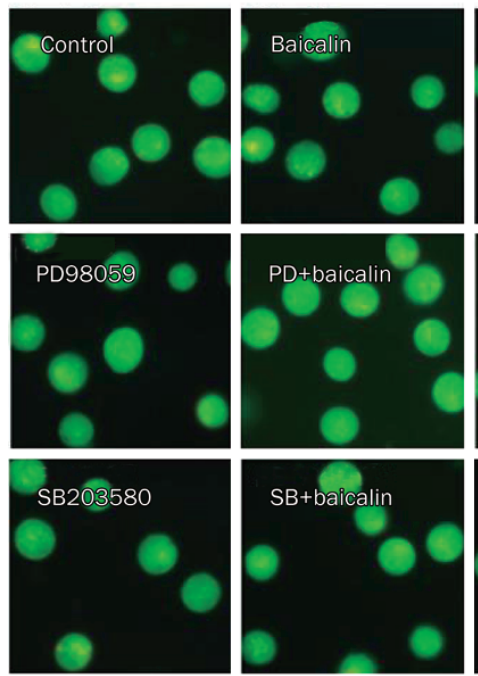
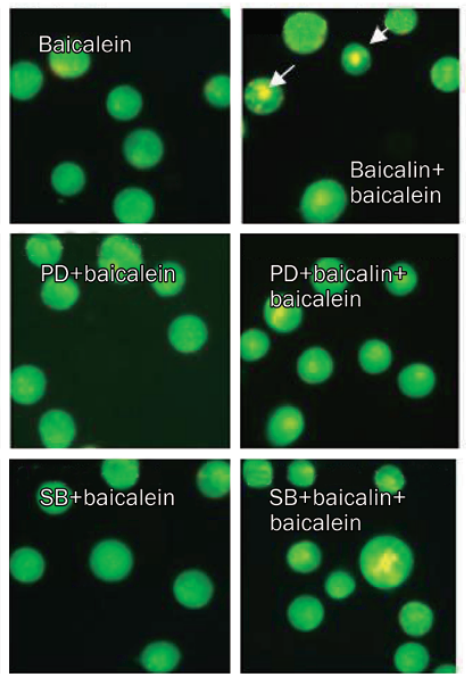

D
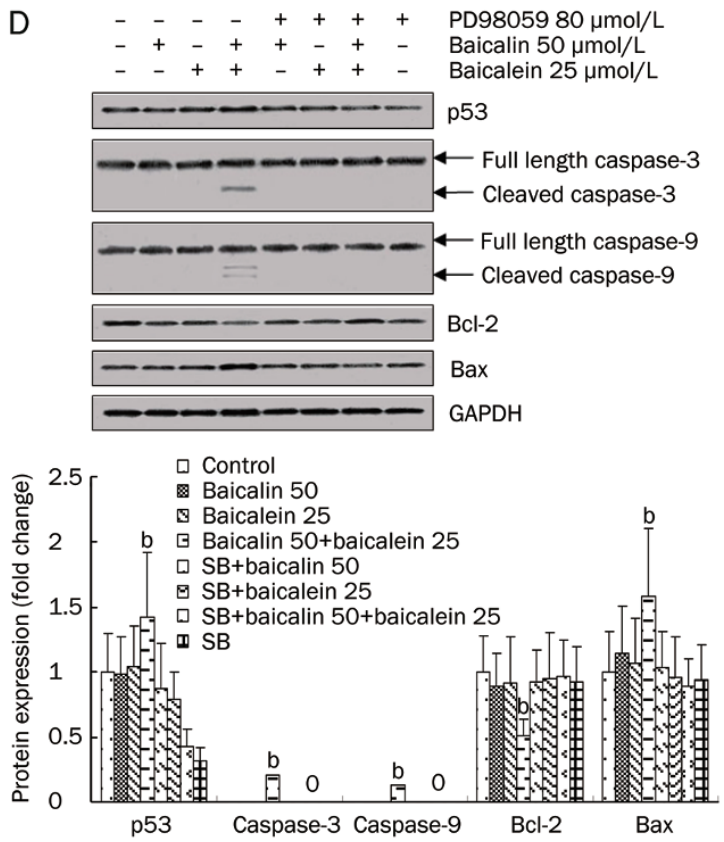

Figure 5. Effect of baicalin $50 \mu \mathrm{mol} / \mathrm{L}$, baicalein $25 \mu \mathrm{mol} / \mathrm{L}$ or their combination on cell growth and apoptosis with or without PD98059 $80 \mu \mathrm{mol} / \mathrm{L}$ and SB203580 $15 \mu \mathrm{mol} / \mathrm{L}$. After MCF-7 cells were pre-treated with or without SB203580 $15 \mu \mathrm{mol} / \mathrm{L}$ for $2 \mathrm{~h}$, cells were treated with baicalin $50 \mu \mathrm{mol} / \mathrm{L}$, baicalein $25 \mu \mathrm{mol} / \mathrm{L}$, and baicalin plus baicalein for $48 \mathrm{~h}$. (A) Cell growth was inhibited by combination of baicalin and baicalein via ERK and p38 MAPK pathway. (B) Apoptosis was enhanced by combination of baicalin and baicalein via ERK and p38 MAPK pathway. (C) The levels of p53, caspase-3, -9, bcl-2 and bax were regulated via ERK pathway. The expressions of p53, caspase-3, -9, bcl-2 and bax were observed after baicalin, baicalein or their combination treatment with or without PD98059 in MCF-7 cells. ${ }^{b} P<0.05$ compared with PD98059 plus the combined treatment. (D) The levels of p53, caspase-3, -9, bcl-2 and bax were regulated via p38 MAPK pathway. Proteins were observed after baicalin, baicalein or their combination treatment with or without SB203580 in MCF-7 cells. ${ }^{\mathrm{b}} \mathrm{P}<0.05$ compared with PD98059 plus the combination treatment. Total cellular proteins were extracted and performed with Western blotting analysis. The density ratio of proteins to GAPDH was shown as relative expression. Values are expressed mean \pm SD. $n=3$. Experiments were repeated with similar results.

ment of baicalin and baicalein. Apoptosis was decreased or abolished when cells were treated with the baicalin/baicalein combination and PD98059 or SB203580. Therefore, apoptosis caused by the combination of baicalin and baicalein is dependent on the ERK/p38 MAPK pathway.

To determine whether apoptosis-related proteins are regu- 
lated via the ERK/p38 MAPK pathway, cells were treated with or without PD98059 or SB203580 for $48 \mathrm{~h}$ and then we examined protein levels by Western blot analysis. As shown in Figure $5 \mathrm{C}$, we found that the expression of p53 was increased by $21 \%$ by the combination treatment of baicalin and baicalein, as compared to the untreated control. However, in the presence of PD98059, the level of p53 expression was decreased about $60 \%$, as compared to the combined drug treatment without PD98059. Caspase-3 and caspase-9 cleavage products, as well as decreased bcl-2 levels were observed upon treatment with the combination of baicalin and baicalein for $48 \mathrm{~h}$. However, this effect was abolished by the addition of PD98059. Conversely, the expression of bax remained unchanged when cells were treated by the combination of baicalin and baicalein, with or without PD98059. These data suggest that the regulation of p53, caspase-3, caspase- 9 , and bcl-2 by the combination of baicalin and baicalein is dependent on ERK. The combination of baicalin and baicalein induces apoptosis via the ERK pathway.

As shown in Figure 5D, combined treatment with baicalin and baicalein increased the level of p53 and bax by $22 \%$ and $58 \%$, respectively, and decreased the level of bcl- 2 by $48 \%$, as compared to the untreated control. However, in the presence of SB203580 plus baicalin and baicalein, the level of p53 and bax was decreased by $65 \%$ and $44 \%$, respectively, and the level of bcl-2 expression was increased by $85 \%$, as compared to the combination of baicalin and baicalein without SB203580. We also found that the activation of caspase- 3 and caspase- 9 by the combination of baicalin and baicalein was inhibited by SB203580. These results demonstrate that apoptosis-related proteins such as p53, caspase-3, caspase- 9 , bcl-2, and bax are regulated by the combination of baicalin and baicalein through p38 MAPK.

\section{Discussion}

Cell death is generally presented as having two categories: apoptosis, representing "active" programmed cell death, and necrosis, representing "passive" cell death without (known) underlying regulatory mechanisms ${ }^{[25]}$. The induction of cancer cell apoptosis is a key strategy in anticancer therapy.

In this study, we found concentration-dependent cell growth inhibition in response to baicalin or baicalein alone in both MCF-7 and MDA-MB-231 cells (Figure 1A, 1B), in accordance with previous research in prostate cancer ${ }^{[26]}$ and bladder cancer ${ }^{[27]}$. Notably, treatment with the combination of baicalin and baicalein significantly increased cell growth inhibition, as compared to baicalin or baicalein alone. Cell growth was maximally inhibited by a combined treatment of $50 \mu \mathrm{mol} / \mathrm{L}$ baicalin plus $25 \mu \mathrm{mol} / \mathrm{L}$ baicalein. Moreover, this effect was time-dependent (Figure 1C). According to isobologram analysis, the combination of $50 \mu \mathrm{mol} / \mathrm{L}$ baicalin and $25 \mu \mathrm{mol} / \mathrm{L}$ baicalein had a synergistic effect. These results show that the combined treatment of $50 \mu \mathrm{mol} / \mathrm{L}$ baicalin and $25 \mu \mathrm{mol} / \mathrm{L}$ baicalein enhances the growth inhibition of MCF-7 and MDAMB-231 cells.

Previous reports have shown that baicalin and baicalein both induce apoptosis in prostate cancer cells ${ }^{[28]}$. It also has been reported that there is growth inhibition in breast carcinoma cells in scutellaria extracts and constituent flavonoids that include baicalin and baicalein ${ }^{[29]}$, but this is the first study on the combination of baicalin and baicalein in MCF-7 cells. To clarify whether the effect on cell growth inhibition was due to apoptosis in breast cancer cells, we performed morphological experiments and DNA fragmentation analysis after the combined treatment of baicalin and baicalein for 24 and $48 \mathrm{~h}$ (Figure 2). However, it has been reported that the MCF-7 cell line from ATCC does not produce a typical DNA ladder in response to apoptotic induction ${ }^{[30]}$, though we did not notice this problem in the current study. Nevertheless, to strengthen our conclusion, another breast cancer cell line, MDA-MB-231, was used. Data showed that baicalin in combination with baicalein induced DNA fragmentation in both MCF-7 and MDA-MB-231 cells (Figure 2B).

The apoptosis ratio and cell cycle arrest were analyzed by FACS analysis at different time points in MCF-7 cells. As compared to baicalin or baicalein alone, the apoptosis ratio was increased approximately 10- or 4 -fold, respectively, at $48 \mathrm{~h}$ by the combined treatment of baicalin and baicalein (Table 1). Therefore, these data suggest that the increase in cell growth inhibition was caused by apoptosis. Moreover, the results also show that the combination of baicalin and baicalein induces cell cycle arrest in $\mathrm{G}_{0} / \mathrm{G}_{1}$ phase (Figure 3).

Apoptosis occurs through the extrinsic or cytoplasmic pathway ${ }^{[31]}$ and the intrinsic or mitochondrial pathway ${ }^{[32]}$. However, both the extrinsic and intrinsic apoptotic pathways converge to caspase-3. In the intrinsic pathway, the upstream caspase of caspase-3 is caspase- $-9^{[33]}$. It has been reported that baicalin or baicalein induces apoptosis via mitochondria- and caspase-dependent pathway in human breast cancer MDAMB-231 cells ${ }^{[16]}$ and prostate cancer cells ${ }^{[34]}$. In this study, caspase- 9 and caspase- 3 were activated by the combined treatment of baicalin and baicalein at 24 and $48 \mathrm{~h}$ in MCF-7 cells (Figure 4A). Recently, one study revealed that the MCF-7 cell line from ATCC lacks functional caspase- $3^{[35]}$. While we did not notice this problem in our experiments, we used the MDAMB-231 cell line to confirm our data. In these cells, caspase-3 and caspase- 9 were also activated by the combined treatment of baicalin and baicalein (Figure 4B). These data suggest that caspase- 9 and caspase- 3 are activated as mechanisms of combined drug-induced apoptosis.

The overexpression of bcl-2 in the intrinsic pathway may lead to the inhibition of the extrinsic pathway of apoptosis. The ratio of pro-apoptotic bcl-2 family members (eg, bax, bad, and bak) to anti-apoptotic bcl-2 family members increases, and pores form in the outer mitochondrial membrane, liberating apoptogenic mitochondrial proteins to activate caspases and to induce apoptosis ${ }^{[36]}$. It has been revealed that baicalin induces apoptosis via the inhibition of bcl-2 and loss of bax in the prostate cancer cell line DU145 $5^{[?]}$. We found that bcl-2 expression was decreased and bax expression was increased by the combined treatment of baicalin and baicalein, as compared to baicalin or baicalein alone. These data suggest that 
the combined drug-induced apoptosis does not only involve the intrinsic pathway, but also acts through the downregulation of bcl-2 and upregulation of bax.

P53, which is the most commonly mutated gene in human cancers, functions as a transcription factor regulating downstream genes in apoptosis ${ }^{[37]}$. It has been reported that p53-dependent apoptosis is induced in MCF-7 cells ${ }^{[38]}$. In this study, the level of p53 was upregulated by the combined drug treatment. These data show that p53 is involved in the combined drug-induced apoptotic process.

As described above, the combined treatment of baicalin and baicalein increased apoptosis in MCF-7 cells, as compared to baicalin or baicalein alone, and the induction of apoptosis was related to caspase-9, -3 , bax, p53, and bcl-2. It has been reported that apoptosis induced by baicalin involves the upregulation of p53 and bax in MCF-7 cells ${ }^{[18]}$. This was not the case in our study. In our experiments, we used the lowest concentration of baicalin or baicalein that did not cause significant cell growth inhibition. Consequently, neither $50 \mu \mathrm{mol} / \mathrm{L}$ baicalin nor $25 \mu \mathrm{mol} / \mathrm{L}$ baicalein alone changed the expression of some apoptosis-related proteins. However, the combined drug treatment showed synergistic effect and inhibited cell growth. Therefore, we explored the mechanisms of the combined drug treatment.

Previous research has shown that baicalin- or baicaleininduced apoptosis involved multi-molecular mechanisms ${ }^{[16,31]}$. Therefore, we asked which signaling pathways were activated by the combined treatment of baicalin and baicalein.

P38 MAPK is involved in regulating cellular responses to stress and cytokines ${ }^{[39]}$. It has been reported that cell survival and apoptosis are regulated through the ERK/MAPK pathway in various cancer cells ${ }^{[40]}$. Some monomeric compounds derived from plants, such as quercetin ${ }^{[41]}$ and silibinin ${ }^{[42]}$, were studied. Their anti-cancer properties were regulated by the ERK/p38 MAPK signaling pathways. It has also been reported that baicalein's effects involve ERK ${ }^{[43]}$ and the phosphorylation of $\mathrm{p} 38 \mathrm{MAPK}$ and $\mathrm{AKT}^{[44]}$. However, there have been no studies on the mechanism of the combination of baicalin and baicalein via ERK and p38 MAPK in MCF-7 cells.

To assess the role of ERK and p38 MAPK in the combined treatment of baicalin and baicalein, cells were stimulated with the ERK specific inhibitor, PD98059, and the p38 MAPK specific inhibitor, SB203580, alone and with different drugs. The data show that both PD98059 and SB203580 decrease or abolish the cell growth inhibitory effect and apoptosis that is induced by the combination of baicalin and baicalein. These data suggest that the combined treatment inhibits cell growth and enhances apoptosis via ERK and p38 MAPK. The levels of p53, caspase-3, caspase- 9 , and bcl-2 were regulated by the combination of baicalin and baicalein via the ERK pathway, but the expression of bax remained unchanged by the combined treatment with or without PD98059 (Figure 5C). However, the levels of p53, caspase- 3 and caspase- 9 , bcl-2, and bax were all regulated by the combination of baicalin and baicalein via the p38 MAPK pathway (Figure 5D). Therefore, we conclude that the combination of baicalin and baicalein enhances apoptosis via the ERK pathway and the p38 MAPK pathway in MCF-7 cells. These data demonstrate the multi-targeting effects of the combination of baicalin and baicalein, as opposed to baicalin or baicalein alone.

When two drugs produce the same broad therapeutic effect, their combination produces the same effect to some magnitude, as compared to the summed effects of the individual drugs. A combination of drugs is pharmacodynamically synergistic if the effect is greater than the summed effects of the partner drugs ${ }^{[45]}$. Synergistic drug combinations have been explored to achieve one or more favorable outcomes, such as enhanced efficacy and decreased dosage at an equal or increased level of efficacy ${ }^{[46]}$. In one study, curcumin was tested for its ability to compromise the proapoptotic activity of camptothecin, alkylating agents and anthracyclines ${ }^{[47]}$. In other studies, curcumin instead showed synergistic growth inhibition and stimulated apoptosis in some cancer cells when combined with chemotherapeutic drugs such as bortezomib and 5-fluorouracil ${ }^{[48]}$. Therefore, the combined effect of the substances likely depends on drug-drug interactions. In this study, the levels of p53, caspase-9, caspase-3, bax, and bcl-2 were not changed significantly by baicalin or baicalein alone. But the expressions of these proteins were upregulated or downregulated by the combination of baicalin and baicalein. As such, we conclude that the combination treatment produced a synergistic effect. These data suggest that combination treatment with natural products is a viable research approach for the discovery of new anticancer agents.

In conclusion, the combination treatment with baicalin and baicalein enhances apoptosis in MCF-7 cells, activates caspase- 9 and caspase- 3 , downregulates bcl-2 and upregulates bax and $\mathrm{p} 53$ via the ERK/p38 MAPK pathway.

\section{Acknowledgements}

This work was financially supported by MOST of China (No 2006BAI08B02-06), the Shanghai Municipal Education Commission Project (№ 08YZ54 and 07ZZ51) and the E-institutes of Shanghai Municipal Education Commission (№ E 03008).

\section{Author contribution}

Shi-bing SU designed experiments; Qian-mei ZHOU and Song WANG performed the main experiments; Hui ZHANG and Xiu-feng WANG performed partial experiments; Yi-yu LU analyzed data; Qian-mei ZHOU wrote the paper and Yoshiharu MOTOO revised the paper.

\section{References}

1 Desai AG, Qazi GN, Ganju RK, El-Tamer M, Singh J, Saxena AK, et al. Medicinal plants and cancer chemoprevention. Curr Drug Metab 2008; 9: 581-91.

2 Parkin DM, Bray F, Ferlay J, Pisani P. Global cancer statistics, 2002. CA Cancer J Clin 2005; 55: 74-108.

3 Soerjomataram I, Louwman MW, Ribot JG, Roukema JA, Coebergh JW. An overview of prognostic factors for long-term survivors of breast cancer. Breast Cancer Res Treat 2008; 107: 309-30.

4 Anderson BO, Jakesz R. Breast cancer issues in developing countries: an overview of the breast health global initiative. World J Surg 2008; 
32: 2578-85.

5 Wu J. Apoptosis and angiogenesis: two promising tumor markers in breast cancer (review). Anticancer Res 1996; 16: 2233-9.

6 Tamm I, Schriever F, Dorken B. Apoptosis: implications of basic research for clinical oncology. Lancet Oncol 2001; 2: 33-42.

7 Furth PA. Introduction: mammary gland involution and apoptosis of mammary epithelial cells. J Mammary Gland Biol Neoplasia 1999; 4: 123-7.

8 Huang $\mathrm{Z}$. Bcl-2 family proteins as targets for anticancer drug design. Oncogene 2000; 19: 6627-31.

9 Kim R, Tanabe K, Uchida Y, Emi M, Inoue H, Toge T. Current status of the molecular mechanisms of anticancer drug-induced apoptosis. The contribution of molecular-level analysis to cancer chemotherapy. Cancer Chemother Pharmacol 2002; 50: 343-52.

10 Simstein R, Burow M, Parker A, Weldon C, Beckman B. Apoptosis, chemoresistance, and breast cancer: insights from the mcf-7 cell model system. Exp Biol Med 2003; 228: 995-1003.

11 Lee JJ, Kim SY, Chung HC, Lee KH, Song HS, Kang WK, et al. A multicenter phase II study of S-1 plus paclitaxel as first-line therapy for patients with advanced or recurrent unresectable gastric cancer. Cancer Chemother Pharmacol 2009; 63: 1083-90.

12 Vici P, Di Lauro L, Sergi D, Foggi P, Viola G, Mottolese M, et al. A phase II trial of docetaxel and vinorelbine in patients with advanced breast cancer previously treated with anthracyclines. Oncology 2008; 75: 175-81.

13 Groth-Pedersen L, Ostenfeld MS, Høyer-Hansen M, Nylandsted J, Jäättelä M. Vincristine induces dramatic lysosomal changes and sensitizes cancer cells to lysosome-destabilizing siramesine. Cancer Res 2007; 67: 2217-25.

14 Motoo Y, Sawabu N. Antitumor effects of saikosaponins, baicalin and baicalein on human hepatoma cell lines. Cancer Lett 1994; 86 : 91-5.

15 Ikezoe T, Chen SS, Heber D, Taguchi H, Koeffler HP. Baicalin is a major component of PC-SPES which inhibits the proliferation of human cancer cells via apoptosis and cell cycle arrest. Prostate 2001; 49: 285-92.

16 Lee JH, Li YC, Ip SW, Hsu SC, Chang NW, Tang NY, et al. The role of $\mathrm{Ca}^{2+}$ in baicalein-induced apoptosis in human breast MDA-MB231 cancer cells through mitochondria- and caspase-3-dependent pathway. Anticancer Res 2008; 28: 1701-11.

17 Parajuli P, Joshee N, Rimando AM, Mittal S, Yadav AK. In vitro antitumor mechanisms of various Scutellaria extracts and constituent flavonoids. Planta Med 2009; 75: 41-8.

18 Wang N, Tang LJ, Zhu GQ, Peng DY, Wang L, Sun FN, et al. Apoptosis induced by baicalin involving up-regulation of p53 and bax in MCF-7 cells. J Asian Nat Prod Res 2008; 10: 1129-35.

19 Makin G, Dive C. Modulating sensitivity to drug-induced apoptosis: the future for chemotherapy? Breast Cancer Res 2001; 3: 150-3.

20 Schaeffer HJ, Weber MJ. Mitogen-activated protein kinases: specific messages from ubiquitous messengers. Mol Cell Biol 1999; 19: 2435-44.

21 Xia Z, Dickens M, Raingeaud J, Davis RJ, Greenberg ME. Opposing effects of ERK and jNK-p38 MAPK kinases on apoptosis. Science 1995; 270: 1326-31.

22 Azzam DG, Tay JW, Greeve MA, Harvey JM, Bentel JM. ERK/MAPK regulation of the androgen responsiveness of breast cancer cells. Adv Exp Med Biol 2008; 617: 429-35.

23 Chou TC, Talalay P. Quantitative analysis of dose-effect relationships: the combined effects of multiple drugs or enzyme inhibitors. Adv Enzyme Regul 1984; 22: 27-55.

$24 \mathrm{Ju} \mathrm{XH}, \mathrm{Xu}$ YH, Li Y. Effects of pseudolaric acid B on the apoptosis, mitochondrial membrane potential and cyclooxygenase-2 expression in hepatocellular carcinoma cell line BEL-7402. World Chin J Digestol 2008; 16: 1151-6. Chinese.

25 Herr I, Debatin KM. Cellular stress response and apoptosis in cancer therapy. Blood 2001; 98: 2603-14.

26 Ikezoe T, Chen SS, Heber D, Taguchi H, Koeffler HP. Baicalin is a major component of PC-SPES which inhibits the proliferation of human cancer cells via apoptosis and cell cycle arrest. Prostate 2001; 49: 285-92.

27 Chao JI, Su WC, Liu HF. Baicalein induces cancer cell death and proliferation retardation by the inhibition of $\mathrm{CDC} 2$ kinase and survivin associated with opposite role of p38 mitogen-activated protein kinase and AKT. Mol Cancer Ther 2007; 6: 3039-48.

28 Chen S, Ruan Q, Bedner E, Deptala A, Wang X, Hsieh TC, et al. Effects of the flavonoid baicalin and its metabolite baicalein on androgen receptor expression, cell cycle progression and apoptosis of prostate cancer cell lines. Cell Prolif 2001; 34: 293-304.

29 Parajuli P, Joshee N, Rimando AM, Mittal S, Yadav AK. In vitro antitumor mechanisms of various scutellaria extracts and constituent flavonoids. Planta Med 2009; 75: 41-8.

30 Gooch JL, Yee D. Strain-specific differences in formation of apoptotic DNA ladders in MCF-7 breast cancer cells. Cancer Lett 1999; 144: 31-7.

31 Zapata JM, Pawlowski K, Haas E, Ware CF, Godzik A, Reed JC. A diverse family of proteins containing tumor necrosis factor receptorassociated factor domains. J Biol Chem 2001; 276: 24242-52.

32 Hockenbery D, Nuñez G, Milliman C, Schreiber RD, Korsmeyer SJ. $\mathrm{Bcl}-2$ is an inner mitochondrial membrane protein that blocks programmed cell death. Nature 1990; 348: 334-6.

33 Ghobrial IM, Witzig TE, Adjei AA. Targeting apoptosis pathways in cancer therapy. CA Cancer J Clin 2005; 55: 178-94.

34 Chan FL, Choi HL, Chen ZY, Chan PS, Huang Y. Induction of apoptosis in prostate cancer cell lines by a flavonoid, baicalin. Cancer Lett 2000; 160: 219-28.

35 Jänicke RU. MCF-7 breast carcinoma cells do not express caspase-3. Breast Cancer Res Treat 2009; 117: 219-21.

36 Adams JM, Cory S. The bcl-2 protein family: arbiters of cell survival. Science 1998; 281: 1322-6.

37 Yu J, Wang Z, Kinzler KW, Vogelstein B, Zhang L. PUMA mediates the apoptotic response to $\mathrm{p} 53$ in colorectal cancer cells. Proc Natl Acad Sci USA 2003; 100: 1931-6.

38 Zhuang ZG, Fei F, Chen Y, Jin W. Suberoyl bis-hydroxamic acid induces p53-dependent apoptosis of MCF-7 breast cancer cells. Acta Pharmacol Sin 2008; 29: 1459-66.

39 Lee JC, Laydon JT, McDonnell PC, Gallagher TF, Kumar S, Green D, et al. A protein kinase involved in the regulation of inflammatory cytokine biosynthesis. Nature 1994; 372: 739-46.

40 Gao J, Tian J, Lv Y, Shi F, Kong F, Shi H, et al. Leptin induces functional activation of cyclooxygenase-2 through JAK2/STAT3, MAPK/ERK, and $\mathrm{PI} 3 \mathrm{~K} / \mathrm{AKT}$ pathways in human endometrial cancer cells. Cancer Sci 2009; 100: 389-95.

41 Nam TW, Yoo Cl, Kim HT, Kwon CH, Park JY, Kim YK. The flavonoid quercetin induces apoptosis and inhibits migration through a MAPKdependent mechanism in osteoblasts. J Bone Miner Metab 2008; 26: 551-60.

42 Li L, Gao Y, Zhang L, Zeng J, He D, Sun Y. Silibinin inhibits cell growth and induces apoptosis by caspase activation, downregulating survivin and blocking EGFR-ERK activation in renal cell carcinoma. Cancer Lett 2008; 272: 61-9.

43 Peng CY, Pan SL, Huang YW, Guh JH, Chang YL, Teng CM. Baicalein attenuates intimal hyperplasia after rat carotid balloon injury 
through arresting cell-cycle progression and inhibiting ERK, Akt, and NF-kappaB activity in vascular smooth-muscle cells. Naunyn Schmiedebergs Arch Pharmacol 2008; 378: 579-88.

44 Chao JI, Su WC, Liu HF. Baicalein induces cancer cell death and proliferation retardation by the inhibition of CDC2 kinase and survivin associated with opposite role of p38 mitogen-activated protein kinase and AKT. Mol Cancer Ther 2007; 6: 3039-48.

45 Chou TC. Theoretical basis, experimental design, and computerized simulation of synergism and antagonism in drug combination studies. Pharmacol Rev 2006; 58: 621-81.
46 Jia J, Zhu F, Ma XH, Cao ZW, Li YX, Chen YZ. Mechanisms of drug combinations: interaction and network perspectives. Nat Rev 2009; 8: 111-28.

47 Somasundaram S, Edmund NA, Moore DT, Small GW, Shi YY, Orlowski RZ. Dietary curcumin inhibits chemotherapy-induced apoptosis in models of human breast cancer. Cancer Res 2002; 62: 3868-75.

48 Du B, Jiang L, Xia Q, Zhong L. Synergistic inhibitory effects of curcumin and 5-fluorouracil on the growth of the human colon cancer cell line HT-29. Chemotherapy 2006; 52: 23-8.

\title{
WorldPharma 2010
}

\author{
July 17-23, 2010, Copenhagen, Denmark
}

For detailed information, please login

http://www.worldpharma2010.org 